\title{
Genetic Polymorphism of Estrogen Hormone Receptor (Exon C) Gene in Buffaloes
}

\author{
R.S. Kathiravan ${ }^{1 *}$, R. Chitra $^{2}$, N. Murali ${ }^{1}$ and M. Arthanarieswaran ${ }^{3}$ \\ ${ }^{1}$ Department of Animal Genetics and Breeding, ${ }^{2}$ Department of Animal Husbandry Statistics \\ and Computer Applications, Veterinary College and Research Institute, \\ Namakkal, Tamil Nadu, India \\ ${ }^{3}$ Veterinary University Training and Research Centre, Tirupur, Tamil Nadu, India \\ *Corresponding author
}

A B S T R A C T

Keywords

PCR-RFLP, ER $\alpha$ gene, Exon $\mathrm{C}$, Buffalo

Article Info

Accepted:

24 January 2018

Available Online:

10 February 2018
Estrogen hormone is an important hormone found to be linked with reproductive traits and affect the growth, differentiation and function of reproductive tissues. Estrogen receptor gene $(E R \alpha)$ is considered as candidate marker for fertility traits in farm animals. The present study was undertaken with 203 buffaloes from different locations. The Polymerase Chain Reaction-Restriction Fragment Length Polymorphism (PCR-RFLP) of ER- $\alpha$ gene revealed monomorphic pattern at 171 and $77 \mathrm{bp}$ and genotyped as $G G$ for all the tested animals, which indicates the fixation of allele. As a conclusion, monomorphic pattern of Estrogen Receptor- $\alpha$ $(E R \alpha)$ gene is considered a unique feature that may be related to the characteristic of buffaloes.

\section{Introduction}

Livestock is an important source of human foods such as milk, meat and eggs and also a source of employment to the farmers to provide income. Indian livestock sector is one of the largest livestock sectors in the world. India is an excellent reservoir of livestock biodiversity in the form of species, breed and strains. The current world buffalo population is 194 million and in India 108.7 million buffaloes are reared. India ranks first in buffalo population and accounts for nearly 58 $\%$ of world population. Based on the report of National Bureau of Animal Genetic Resources (NBAGR), Karnal, there are 13 registered breeds of buffaloes in India. The buffaloes have the capacity to adapt to the local management, poor feeds and are resistant to certain tropical diseases.

India produces about two third of the world buffalo milk production and buffalo contributes more than fifty percent milk of the 
total milk produced in India (Rani et al., 2016). The buffalo productivity is significantly affected by inherent problems such as low reproductive efficiency, which is mainly due to late maturity, poor expression of oestrus, anoestrus, inactive ovaries, long postpartum interval, seasonality in cyclicity and silent oestrus (Minji et al., 2008; Sosa et al., 2016).

The reproductive performances are mainly affected by many hormones coupled with their respective receptors in field buffaloes. Estrogen hormone isan important hormone found to be linked with reproductive traits and affect the growth, differentiation and function of reproductive tissues like mammary gland, ovary, uterus (Szreder and Zwierzchowski 2004; Eng et al., 1997). Estrogen receptors are members of nuclear receptors superfamily to which estrogen bind and regulate gene expression by interacting with specified intracellular receptor proteins (Sarla et al., 2015). Hence estrogen receptor gene is considered as candidate marker for fertility traits in farm animals. Two forms of estrogen receptor i.e, $\alpha$ and $\beta$ are present in mammals (Sarla et al., 2009; Enmark and Agustafsson 1998).

Genetic improvement of buffalo productivity has been dependent on concepts of quantitative genetics of various productivity traits of economic importance to promote more efficient and relatively easy selection of Indian buffaloes. The use of polymorphism in candidate genes for marker assisted selection may increase the genetic gain achieved by selection as a result of more accurately predicted breeding values (Pamentierr et al., 1999).

\section{Materials and Methods}

The present study was conducted in the organised farms viz., Saraswathi Krishi
Vigyan Kendra, Karur district, Tamil Nadu; Post Graduate Research Institute in Animal Sciences (TANUVAS), Katupakkam, Tamil Nadu; Central Cattle Breeding Farm, Alamadhi, Chennai, Tamil Nadu; Buffalo Research Station, Venkataramanna Gudem, S.V.V.U, West Godavari District, Andhra Pradesh and Farmers herd in Namakkal, Tamil Nadu. A total of 203 blood samples were collected from jugular vein aseptically in the vaccutainer containing EDTA as anticoagulant. Genomic DNA from whole blood was extracted by using the standard high salt method as described by Miller et al., (1988) with minor modifications. The isolated DNA was checked for quality, purity and concentration by Nanodrop and agarose gel electrophoresis. A region of estrogen receptor $\alpha(E R \alpha)$ gene spanning over a part of exon $\mathrm{C}$ was amplified by using specific primers with different PCR cycling program (Table 1).

The PCR products were checked by agarose gel electrophoresis to confirm the amplification before analysing for polymorphism. The PCR product was digested with $B g l \mathrm{I}$ for genotyping in a final reaction volume of $15 \mu \mathrm{l}$, containing7 $\mu \mathrm{l}$ PCR product, and 10 units enzyme and incubated at $37^{\circ} \mathrm{C}$ for overnight. Ten microliter of the digested samples were separated by electrophoresis on 2per cent agarose gel in $1 \mathrm{X}$ TAE buffer containing ethidium bromide at $2 \mathrm{~V} / \mathrm{cm}$ for 1hour to determine the genotypes. The gels were visualised and the images were documented in a gel documentation system (Bio-Rad Gel Doc ${ }^{\mathrm{TM}}$ ).

\section{Results and Discussion}

$E R \alpha($ exon C) / BglI digestion of 248 bp PCR products was carried out and were run in 2.0 per cent agarose gel to visualize the bands and to genotype the individuals. All the PCR products showed monomorphic condition at 171 and 77 bp. Differentiation of the 
genotypes based on fragments are as follows; $A A$ with undigested fragment at 248-bp, $G G$ with two digested fragments at 171- and 77-bp and $A G$ with three digested fragments at 248-, 171- and 77-bp (Othman and Abdel-Samad 2013). All the samples under study showed bands of 171 and $77 \mathrm{bp}$ corresponding to the $G G$ genotype (Fig. 1). Contradictory result was revealed by Othman and Abdel-Samad
(2013) as two genotypes namely $A G$ and $G G$ with frequency of 0.18 and 0.82 respectively in Egyptian buffalo.

Similar monomorphic pattern of $E R \alpha$ (exon 13) was obtained with $M b o$ I restriction enzyme by Sarla et al., (2015) in Murrah buffalo maintained at Central Institute for Research on Buffaloes, Hisar.

Table.1 Primers (forward and reverse) along with the properties and steps used for amplification of $248 \mathrm{bp}$ exonC portion of ER $\alpha$ gene

\begin{tabular}{|c|c|c|c|c|c|}
\hline Gene name & \multicolumn{3}{|c|}{ Sequence } & $T_{m}$ value & $\begin{array}{c}\text { Expected } \\
\text { PCR product } \\
\text { size (bp) }\end{array}$ \\
\hline $\begin{array}{l}E R a \\
\text { (exon C) }\end{array}$ & \multicolumn{3}{|c|}{$\begin{array}{l}\text { F: TTT GGT TAA CGA GGT GGA G } \\
\text { R: TGT GAC ACA GGT GGT TTT TC }\end{array}$} & $\begin{array}{l}50 \\
51\end{array}$ & 248 \\
\hline \multicolumn{6}{|c|}{ PCR Steps } \\
\hline $\begin{array}{c}\text { Initial } \\
\text { Denaturation } \\
(1) \\
\end{array}$ & $\begin{array}{c}\text { Denaturation } \\
\text { (2) }\end{array}$ & $\begin{array}{c}\text { Annealing } \\
\text { (3) }\end{array}$ & $\begin{array}{l}\text { Extension } \\
\text { (4) }\end{array}$ & $\begin{array}{c}\text { No. of cycles } \\
\text { from step } 2-4 \\
(5)\end{array}$ & $\begin{array}{c}\text { Final } \\
\text { Extension } \\
(6)\end{array}$ \\
\hline $94^{\circ} \mathrm{C} / 5 \min$ & $94^{\circ} \mathrm{C} / 1 \mathrm{~min}$ & $\begin{array}{c}56^{\circ} \mathrm{C} / 1 \\
\min \end{array}$ & $\begin{array}{c}72^{\circ} \mathrm{C} / 1 \\
\text { min }\end{array}$ & 30 & $\begin{array}{l}72^{\circ} \mathrm{C} / 10 \\
\min \end{array}$ \\
\hline
\end{tabular}

$\mathrm{T}_{\mathrm{m}}-$ Melting Temperature

Fig.1 Restriction Fragment Length Polymorphism pattern of $E R-\alpha$ gene with $B g l$ I enzyme in buffaloes

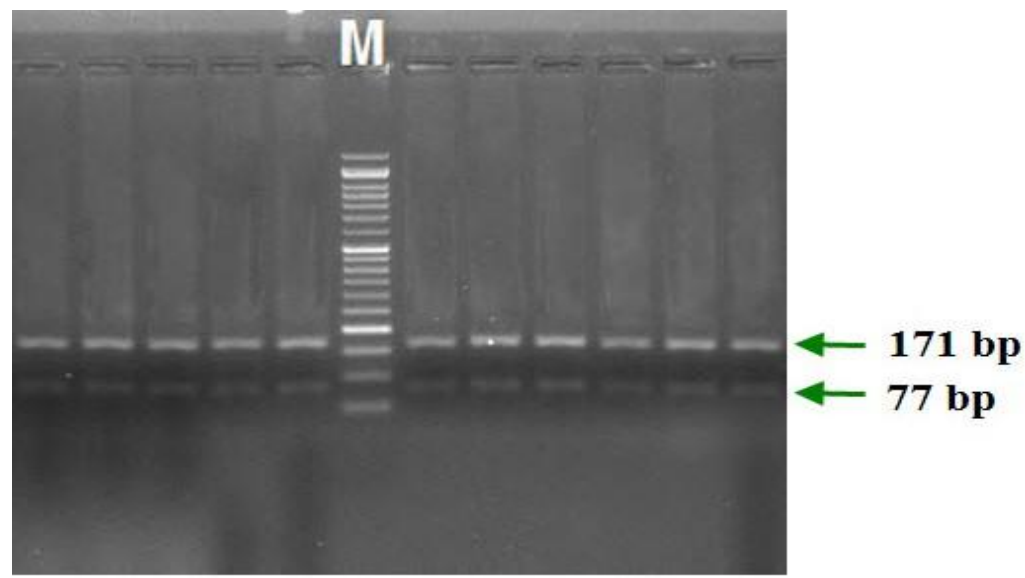

Rani et al., 2016 analyzed the genetic variation of 870 bp ERa (exon 13) gene in Murrah buffaloes by $S t u$ I and $H p a I I$ restriction enzymes and in restriction enzyme digestion of $870 \mathrm{bp}$
PCR products, $305 \mathrm{bp}$ and $565 \mathrm{bp}$ sized two fragments were produced by StuI and 759 bp and $111 \mathrm{bp}$ sizes two fragments were produced by HpaII. Both of these enzyme digestion 
exhibited monomorphic pattern in all animals.

All the tested animals showed monomorphic pattern at 171 and $77 \mathrm{bp}$ and genotyped as GG.GG genotype for all the PCR products of $E R-\alpha$ gene indicates the fixation of allele $\mathrm{G}$ in the buffalo population.

Thus we can conclude that the monomorphic pattern of Estrogen Receptor- $\alpha(E R \alpha)$ gene can be considered a unique feature that may be related to the characteristic of buffaloes.

Further studies should be carried out in other population to clarify whether there are significant differences among animals belonging to different population.

\section{References}

Eng F. C. S., H. S. Lee, J. Ferrara, T. M. Willson and White, J. H. 1997. Probing the structure and function of the 477 estrogen receptor ligand binding domain by analysis of mutants with altered transactivation characteristics. Molecular Cell Biology. 17: 4644-4653.

Enmark E and Gustafsson, JA. 1998. Estrogen receptor $\beta$ - a novel receptor opens up new possibilities for cancer diagnosis and treatment. Endocrinol.-Related Cancer, 5: 213-222.

Miller, S. A., D. D. Dykesand Polesky, H. F. 1988. A simple salting out procedure for extracting DNA from human nucleated cells. Nucleic Acids Research, 16: 1215.

Minj A, S. Mondal, A. K. Tiwari, B. Sharma and Varshney, V. P. 2008. Molecular characterisation of follicle stimulating hormone receptor (FSHR) gene in the Indian River buffalo (Bubalus bubalis).
General and Comparative Endocrinology. 158: 147-153.

Othman, E and Abdel-Samad, M. F. 2013. RFL Polymorphism of three fertility genes in Egyptian buffalo. Journal of applied bioscience. 7(2): 94-101.

Parmentier, L., D. Portelle, N. Gengler, A. Prandi, C. Bertozzi, L. Vleurick and Gilson, R. 1999. Candidate gene markers associated with somatotropic axis and milk selection. Domestic Animal Endocrinology. 17: 139-148.

Rani S, M. Kumar, N. Pradeepkumar, S. K. Phulia and Vinod, C. 2016. ESR $\alpha$ exon polymorphism coupled with protein modeling in relation to reproductive traits in Murrah buffaloes. International Journal of Pharmacy and Biological Sciences. 7(4): 856-868.

Sarla, Mahesh Kumar, S. K. Phulia and Vinod, C. 2015. Genetic Polymorphism in Exon 13 of estrogen receptor- $\alpha(E R \alpha)$ gene in Murrah buffalo (Bubalus bubalis). Annals of Biology. 31(1): 41-45.

Sarla, V. Chhokar and Phulia S. K. 2009. Estrogen receptor gene $-\mathrm{A}$ candidate marker in animal production. Indian Buffalo journal. 7: 102-105.

Sosa, A. S. A, K. Gh. M. Mahmoud, M. M. M. Kandiel, H. A. A. Eldebaky, M. F. Nawito and El-Roos, M. E. A. A. 2016. Genetic polymorphism of leutinizing hormone receptor gene in relation to fertility of Egyptian buffalo. BioTechnology: An Indian Journal. 12(5).

Szreder, T and Zwierzchowski, L. 2004. Polymorphism within the bovine estrogen receptor- $\alpha$ gene 5' region. Journal of Applied Genetics. 45(2): 225-236.

\section{How to cite this article:}

Kathiravan, R.S., R. Chitra, N. Murali and Arthanarieswaran, M. 2018. Genetic Polymorphism of Estrogen Hormone Receptor (Exon C) Gene in Buffaloes. Int.J.Curr.Microbiol.App.Sci. 7(02): 2718-2721. doi: https://doi.org/10.20546/ijcmas.2018.702.330 